\title{
Analisis Proksimat dan Nilai Kesukaaan Beras Artifisial Berbahan Dasar Tepung Ubi Kayu (Manihot esculenta Crantz) dan Tepung Labu Kuning (Cucurbita moschata Durch)
}

\section{Proximate Analysis and Preference Level of Artificial Rice Based on Cassava Flour (Manihot esculenta Crantz) and Yellow Pumpkin Flour (Cucurbita moschata Durch)}

\author{
Dewi Kartika Rahmawati ${ }^{1 *}$, Munifatul Izzati ${ }^{2}$, Sarjana Parman $^{2}$ \\ ${ }^{1}$ Mahasiswa Program Studi Biologi, Departemen Biologi, Fakultas Sains dan Matematika \\ ${ }^{2}$ Departemen Biologi Fakultas Sains dan Matematika Universitas Diponegoro \\ Email: dewix_deuwiq@yahoo.co.id
}

Diterima 1 Agustus 2018 / Disetujui 18 Oktober 2018

\begin{abstract}
ABSTRAK
Beras artifisial adalah beras yang dibuat dari non padi dengan kandungan karbohidrat mendekati atau melebihi beras. Beras artifisial berbahan dasar tepung ubi kayu dan labu kuning merupakan solusi agar ketergantungan masyarakat terhadap beras dapat dikurangi.Penelitian ini bertujuan untuk mengetahui dan mengkaji kandungan gizi beras artifisial berbahan dasar tepung ubi kayu dan labu kuning ditinjau dari analisis proksimat dan antioksidan serta mengetahui dan mengkaji tingkat kesukaan masyarakat. Penelitian ini menggunakan Rancangan Acak Lengkap dengan satu faktor yaitu jumlah perbandingan tepung ubi kayu dan tepung labu kuning yang terdiri dari 3 taraf yaitu formula 2:1, 1:1 dan 1:2. Metode dari penelitian ini meliputi analisis proksimat, analisis antioksidan dan uji nilai kesukaan.Hasil penelitian menunjukkan bahwa formula beras artifisial berbahan dasar tepung ubi kayu dan labu kuning yang memiliki kualitas gizi terbaik yaitu formula 1:2. Formula 1:2 memiliki kadar abu sebesar 3,5\%; kadar a ir 9,2\%; kadar serat kasar 8,2\%;kadar protein $8 \%$; kadar lemak 0,4\%; kadar karbohidrat $78,5 \%$ dan kadar antioksidan $8 \%$. Uji nilai kesukaan menunjukan bahwa beras artifisial berbahan dasar tepung ubi kayu dan labu kuning formula 1:2 kurang disukai dari segi warna, aroma, dan penerimaan umum, namun dari segi rasa panelis rata-rata menyukainya.
\end{abstract}

Kata kunci: beras artifisial, analisis proksimat, antioksidan, nilai kesukaan

\begin{abstract}
Artifisial rice is rice made from non-carbohydrate rice approached or exceeded conventional rice. Making artifisial rice from cassava flour and yellow pumpkin flour is solution for reduced the dependence on rice. This study aims to analyze and assess the nutritional value of artifisial rice made from cassava flour and yellow pumpkin by means of proximate analysis and antioxidants, and to analyze and assess the preference level for artifisial rice. Experimental studies using a Completely Randomized Design (CRD) with one factor, namely the number of comparisons cassava flour to yellow pumpkin flour, consisted of 3 standard formula is 2:1, 1:1 and 1:2. Methods of study proximate analysis, antioxidant analysis and test preferences value. The results show that the formula of artifisial rice that the best nutrition has formula with a ratio of cassava flour and pumpkin 1:2. Formula 1:2 has ash content $3,5 \%$; water content $9,2 \%$; crude fiber content $8,2 \%$; protein $8 \%$; fat content $0,4 \%$; carbohydrate content $78,5 \%$ and antioxidant levels $8 \%$. Test the preferences value show that the artificial rice made from cassava and pumpkin flour formula 1:2 is less preferrence in terms ofcolor, aroma and general acceptance, but panelists like the taste.
\end{abstract}

Keywords: artifisial rice, proximate analysis, antioxidant, preferences value

\section{PENDAHULUAN}

Beras telah menjadi pemasok utama karbohidrat bagi mayoritas masyarakat Indonesia. Ketergantungan masyarakat Indonesia terhadap beras telah menjadi sebuah masalah pangan yang berkelanjutan (Samad,2003). Saat hari pangan 2000, pemerintah mencanangkan ketahanan pangan melalui pengadaan pangan nonberas. 
Solusinya adalah dengan memanfaatkan produk pangan lokal seperti ubi kayu dan labu kuning yang kemudian diolah menjadi beras artifisial. Upaya ini perlu mempertimbangkan 2 hal agar beras artifisial berbahan dasar tepung ubi kayu dan labu kuning dapatdikembangkan secara lebih luas yaitu kualitas gizi dan penerimaan masyarakat. Kualitas gizi bisa dilihat melalui analisis proksimat dan antioksidan, sedangkan untuk penerimaan masyarakat dapat dilihat melalui uji organoleptik. Ubi kayu termasuk bahan pangan yang kaya akan karbohidrat. Tepung ubi kayu memiliki rasa netral (bland) yang menguntungkan karena memungkinkan pencampurannya dengan bermacam-macam bahan makanan lain maupun bumbu-bumbu (Tjahjadi, 1989). Labu kuning (Cucurbita moschata Durch) banya ditemukan di Indonesia. Hasil penelitian pendahuluan yang pernah dilakukan didapatkan 3 formula tepung ubi kayu dan tepung labu kuning yang tepat dalam membentuk tekstur beras artifisial.Formula tersebut yaitu 2:1, 1:1, dan 1:2. Berdasarkan latar belakang tersebut maka perlu dilakukan penelitian lebih lanjut mengenai analisis proksimat, antioksidan dan nilai kesukaan beras artifisialberbahan dasar tepung ubi kayu (Manihot esculenta Crantz) dan labu kuning (Cucurbita moschata Durch).

\section{METODE PENELITIAN}

Bahan penelitian yaitu beras artifisial formula 2:1, 1:1 dan 1:2, $\mathrm{H} 2 \mathrm{SO} 4, \mathrm{NaOH}$, pelarut heksan, selenium, asam sulfat, methanol, aqua. Alat-alat yang digunakandalam penelitian ini adalah: oven, botol timbang, desikator, tang penjepit, gelas krus, tanur, timbangan sartorius, mortal,labu lemak, soklet, labu Kjeldhal, alat kjeltek , pipet, erlenmeyer, kertas saring, corong, tabung reaksi, spektrofotometer, gelas kurs, kompor listrik, kantong plastik, kamera, lembar uji organoleptik.

\section{Penelitian ini dilaksanakan.dengaan}

menggunakan Rancangan Acak Lengkap (RAL) dengan satu faktor yaitu beras artifisial dengan perbandingan tepung ubi kayu dan tepung labu kuning yang terdiri dari 3 taraf yaitu 2:1, 1:1 dan 1:2 dengan masing- masing perlakuan diberi ulangan sebanyak 3 kali. Beras artifisial tersebut kemudian dianalisa kadar abu, air, serat kasar, protein, lemak, karbohidrat, antioksidan dan uji nilai kesukaan.

\section{HASIL DAN PEMBAHASAN}

Abu adalah residu anorganik yang didapatkan setelah proses penghilangan bahanbahan organik yang terkandung dalam suatu bahan (Sudarmadji et al, 1996). Perbedaan jumlah tepung labu kuning pada rasio formula yang menyebabkan terjadinya perbedaan kadar abu. Kadar abu beras artifisial berbahan dasar tepung ubi kayu dan labu kuning berkisar 2,7-3,5\%. Beras artifisial yang dihasilkan masih dikatakan layak untuk dijadikan bahan makanan karena sesuai dengan standar Badan Pengawasan Obat dan Makanan yaitu kadar abu tidak boleh melebihi $4 \%$.

Kadar air beras artificial berbahan dasar tepung ubi kayu dan labu kuning berkisar 8,5-9,2\% yang berarti masih jauh dibawah kadar air pertumbuhan kapang.Perbedaan kandungan kadar air dari ketiga formula beras artifisial tersebut disebabkan karena perbedaan rasio tepung labu kuning dan proses pengeringan yang dilakukan. Proses pengeringan pada penelitian ini menggunakan sinar matahari. Wiryadi ( 2007) menyatakan bahwa proses pengeringan dengan menggunakan sinar matahari mempunyai kelemahan yaitu tidak diketahui suhunya, sehingga sering proses pengeringannya tidak merata akibatnya hanya bagian luar saja yang kering tetapi bagian dalam belum kering akibatnya kapang atau jamur dapat hidup pada bahan tersebut.

Menurut Siregar (2003), serat kasar adalah senyawa yang tidak dapat dicerna dalam organ pencernaan manusia maupun hewan. Serat kasar tersusun atas selulosa, gum, hemiselulosa, pektin dan lignin. Hasil analisis sidik ragam dan

uji Duncan kadar serat kasar (Tabel 1) menunjukkan tidak adanya perbedaan yang nyata antara ketiga formula beras artifisial berbahan dasar tepung ubi kayu dan labu kuning. Hal ini disebabkan karena kadar serat kasar ubi kayu dan labu kuning hampir sama. Kadar serat kasar beras artifisial berbahan dasar tepung ubi kayu dan labu 
kuning masih layak untuk dikonsumsi, karena jumlahnya masih beradadibawah standar yang ditentukan oleh Badan Pengawas Obat dan Makanan yaitu sebesar 36\%.

Lemak adalah suatu golongan senyawa yang bersifat tidak larut dalam air, namun larut dalam pelarut anorganik. Pelarut yang umum digunakan untuk mengukur kadar lemak adalah heksana, dietil eter dan petroleum eter (Sudarmadji et al, 1996). Hasil analisis sidik ragam dan uji Duncan kadar lemak (Tabel 1) menunjukan adanya perbedaan yang nyata antara ketiga formula beras artifisial berbahan dasar tepung ubi kayu dan labu kuning. Hal ini disebabkan karena perbedaan jumlah tepung digunakan sehingga mengakibatkan perbedaan jumlah lemak pada bahan dan juga produk beras artifisial. Penambahan tepung labu kuning menyebabkan kadar air produk meningkat sehingga menyebabkan kadar lemak pada masa tertinggal menurun. Kadar lemak yang rendah dapat menyebabkan umur simpan beras lebih lama. Hal tersebut dikarenakan beras terhindar dari reaksi oksidasi, sehingga beras juga terhindar dari proses ketengikan (Sediaoetama, 1986). Selain itu juga nilai gizi beras dapat tetap dipertahankan.

Tabel 1. Analisis proksimat beras artifisial

\begin{tabular}{|c|c|c|c|}
\hline \multirow[t]{2}{*}{ Proksimat } & \multicolumn{3}{|c|}{ Perbandingan tepung ubi kayu dan tepung labu kuning } \\
\hline & $\mathrm{P} 0$ & $\mathrm{P} 1$ & $\mathrm{P} 2$ \\
\hline Kadar abu $(\%)$ & $2,714^{\mathrm{b}}$ & $3,350^{\mathrm{ab}}$ & $3,564^{\mathrm{a}}$ \\
\hline Kadar air $(\%)$ & $8,547^{\mathrm{c}}$ & $11,294^{\mathrm{a}}$ & $9,227^{\mathrm{b}}$ \\
\hline Kadar serat kasar (\%) & $5,969^{\mathrm{a}}$ & $6,316^{\mathrm{a}}$ & $8,291^{\mathrm{a}}$ \\
\hline Kadar lemak (\%) & $0,753^{\mathrm{a}}$ & $0,904^{\mathrm{a}}$ & $0,492^{b}$ \\
\hline Kadar protein $(\%)$ & $4,930^{\mathrm{b}}$ & $7,133^{\mathrm{a}}$ & $8,076^{\mathrm{a}}$ \\
\hline Kadar karbohidrat (\%) & $83,056^{\mathrm{a}}$ & $77,320^{\mathrm{b}}$ & $78,591^{\mathrm{b}}$ \\
\hline
\end{tabular}

Keterangan : Angka-angka yang diikuti dengan huruf yang sama pada baris yang sama menunjukkan nilai yang tidak berbeda nyata $(\mathrm{P}>0.05)$

Protein berfungsi sebagai zat pembangun dan pengatur (Winarno, 1986). Hasil analisis sidik ragam dan uji Duncan (Tabel 1) kadar protein menunjukan adanya perbedaan yang nyata antara ketiga formula beras artificial berbahan dasar tepung ubi kayu dan labu kuning. Hal ini disebabkan karena perbedaan jumlah tepung yang digunakan sehingga mengakibatkan perbedaan jumlah protein pada bahan baku dan juga pada produk beras artifisial.

Karbohidrat adalah zat gizi penting dalam kehidupan manusia karena berfungsi sebagai sumber energi utama manusia. Karbohidrat dapat memenuhi 60-70\% kebutuhan energi tubuh (Winarno,1986). Hasil analisis sidik ragam dan uji duncan kadar karbohidrat (Tabel 1) menunjukan adanya perbedaan yang nyata antara ketiga formula beras artifisial berbahan dasar tepung ubi kayu dan labu kuning. Hal ini disebabkan perbedaan jumlah tepung yang digunakan sehingga mengakibatkan perbedaan jumlah karbohidrat dalam bahan baku dan juga produk beras artifisial berbahan dasar tepung ubi kayu dan labu kuning. Berdasarkan hasil penelitian diketahui bahwa terjadi penurunan kadar karbohidrat seiring penambahan jumlah tepung labu kuning. Formula beras dengan kadar tepung labu kuning yang semakin rendah menyebabkan kadar karbohidrat semakin tinggi. Hal ini disebabkan karena pada formula ini komposisi tepung ubi kayu lebih banyak dari tepung labu kuning dan ubi kayu sendiri memiliki jumlah karbohidrat yang tinggi (lebih tinggi dari beras). Selain itu, penambahan labu kuning dapat meningkatkan kadar air dalam bahan pangan sehingga menyebabkan menurunya kadar karbohidrat di dalam masa yang tertinggal.

Warna menjadi salah satu parameter yang sangat menentukan kesukaan konsumen terhadap 
suatu produk (Winarno,1986). Hasil penelitian menunjukan bahwa jumlah skor tertinggi dalam uji kesukaan beras artifisial berbahan dasar tepung ubi kayu dan labu kuning pada indikator warna adalah 49 yaitu sampel P1 dengan jumlah persentase 54,44\%.Presentase skor hedonik semakin banyak konsentrasi penggunaan tepung labu kuning, sehingga warna beras akan menjadi semakin kecoklatan dan hal ini kurang disukai oleh panelis.

Pengujian terhadap bau dalam industri pangan dianggap penting karena dengan cepat dapat memberikan hasil penilaian terhadap produk tentang diterima atau tidaknya produk tersebut (Kartika et al, 1988). Hasil penelitian menunjukan bahwa jumlah skor tertinggi dalam uji kesukaan beras artifisial berbahan dasar tepung ubi kayu dan labu kuning pada indikator aroma adalah 48 yaitu sampel P1 dengan jumlah persentase 53,33\%. Presentase skor hedonik semakin meningkat dengan semakin menurunnya konsentrasi tepung labu kuning. Penambahan tepung labu kuning menyebabkan beras akan menghasilkan aroma langu yaitu aroma khas labu kuning.

Uji nilai kesukaan berdasarkan penerimaan umum merupakan penilaian yang didasarkan pada perpaduan aspek warna, aroma dan rasa. Hasil penelitian menunjukan bahwa jumlah skor tertinggi dalam uji kesukaan beras artifisial berbahan dasar tepung ubi kayu dan labu kuning pada indikator penerimaan umum adalah 52 yaitu sampel P1 dengan jumlah persentase $57,78 \%$.

\section{KESIMPULAN}

Beras artifisial berbahan dasar tepung ubi kayu dan labu kuning yang memiliki kualitas gizi paling baik adalah formula 1:2 dengan kadar abu sebesar 3,5\%; kadar air 9,2\%; kadar serat kasar $8,2 \%$; kadar protein $8 \%$; kadar lemak $0,4 \%$; kadar karbohidrat $78 \%$, dan kadar antioksidan yang cukup tinggi yaitu sebesar $8 \%$. Secara umum, warna dan aroma beras artifisial berbahan dasar tepung ubi kayu dan labu kuning kurang disukai panelis namun dari segi rasa panelis ratarata menyukainya.

\section{DAFTAR PUSTAKA}

Kartika, B. 1988. Pedoman Uji Inderawi Bahan Pangan. UGM.Yogyakarta.

Papas A.S. et al. 1991. Geriatric Denstistry, Aginf and Oral Health, Mosby Year Book. Amerika.

Samad M.Y. 2003. Pembuatan Beras Artifisial dengan Bahan Baku Ubi Kayu dan Sagu.Prosiding Seminar Teknologi untuk Negeri 2003. Vol. II. Hal 36- 40/HumasBPPT/ANY,BPPT. Jakarta. Sediaotama, A.J. 1986. Ilmu Gizi untuk Mahasiswa Profesi. Dian Rakyat. Jakarta Timur.

Siregar, M. 2003. Analisis Proksimat. Penebar Swadaya. Jakarta.

Sudarmadji, Slamet, dkk. 1996. Analisa Bahan Seminar Nasional Peningkatan Nilai Tambah Singkong. Universitas Padjajaran. Bandung

Winarno, F.G. 1986. Kimia Pangan dan Gizi. PT. Gramedia. Jakarta.

Wirakusumah.2010. Jus Buah dan Sayuran.Cetakan 9. Penebar Swadaya. Jakarta. Hal 56. 